\title{
TASK FOR POST-CRISIS IN ROMANIA: THE DEVELOPMENT OF INDUSTRY
}

\author{
Marcela-Cornelia Danu \\ "Vasile Alecsandri" University of Bacău \\ marceladanu@ub.ro
}

\begin{abstract}
The present paper illustrates the role of industry in economic and social development of Romania, in the context of the propagated effects of the contemporary economic and financial crisis and mission that is in the recovery of gaps in relation to EU countries. The dynamic of the industrial sector after 1989, highlighting the continuing decline in its contribution to the GDP formation and changing industry structure in favor of industries producing consumer goods. The situation has changed, however, after the crisis, the industry producing capital goods coming back in force, and hosting the entire sector. Significant is that the development of the Romanian industry must integrate into a viable and sustainable formula, scientific research and technological development with environmental quality. Moreover, the qualitative and quantitative dimensions of industrial development in Romania should be integrated in the dynamic dimensions of the EU, with all the implications and costs derived from this, in the short term. The plea for industrial development in the post-crisis period is supported by the need to ensure a solid foundation for the development of other economic activities specific to the primary and tertiary sectors.
\end{abstract}

\section{Keywords}

industry development; industry structure; scientific research; industrial policy; integration of industry

\section{JEL Classification}

L16; L52; L60; O14; O25

\section{Romanian industry in the context of the contemporary economic crisis}

The economic and financial crisis has affected entire contemporary economic system in Romania from the second semester of 2008. The negative effects of the crisis have been propagated in time and space - also of the component of the economic system, for the most part, involvement the mark of the scientific research and technological development: the industry.

Even if the effects on the Romanian industry crisis were visible, a positive dimension of specific period crisis in Romania is a good integration of this sector of activity in the single European market. The relatively small differences between the trend in European industry and the Romanian have been reported the potential for the restoration of the latter. In 2008 the industrial production in Romania has recorded a significant increase of $0.9 \%$ but in the last quarter followed a negative developments continued and in the first months of 2009. According to INS, considering fixed base year 2005 (100), the industrial production indices analysis in gross series submits that, in the period 2000 to 2009, the maximum amount of monthly industrial production was reached in october 2008. After this month followed by installing powerful decline of industrial production in such a way that, in january 2009 it has fallen from october 2008 with 37\%. February 2009 marks the reverse evolution and completion of a stage of the restructuring in the industrial sector. [http://www.cnp.ro/studii]. Having regard 
to the elements of seasonality, for the period under consideration, it can be concluded that the profile of the trend in time of the evolution of industrial production has been:

- $\quad$ Slowing the evolution of industrial production from march 2008;

- Emphasize the steady decline in the last quarter of 2008, with a minimum in december 2008;

- Resumption of growth, from 1 january 2009, from one month to the other, of the volume of industrial production;

- $\quad$ Return industrial production to a level comparable to that reached in 2008 with a dynamic which is slower, compared the speed at which it has produced its reduction at the end of 2008.

As regards the structural profile of Romanian industry (per division CAEN Rev2), the contraction in demand for various industrial products was followed by policies and strategies related determinands of demand. The results obtained have allowed the industrial activities such as [http://www.cnp.ro/ro/studii]:

1. Industrial activities with general difficulties, whose reduction of production are not determined solely by the crisis effects;

2. Industrial activities affected by the crisis;

3. Activities which have not been affected by the crisis.

1. Industrial activities with general difficulties:

- The light industry, in particular the manufacture of garments, which is located in a longest restructuring process, started with the restriction of activity of inward processing;

- The extraction of gross petroleum and natural gas, activity which, as a matter of fact, has registered, starting from the 2001, successive reductions of production, annually, an average of $4-5 \%$.

2. Industrial activities affected by the crisis - the most of industries, most of them for the export. Among the interdependent causes of the effects of contemporary economic and financial crisis on these activities have been:

- $\quad$ external market reduction, against the background of the economic crisis main partner countries of Romania (Italy, France, Germany, etc. );

- $\quad$ reduction of the volume of credits granted to companies by commercial banks, as a result of central bank (BNR) rules;

- reduction of activity in the construction sector, causing drop in production in the industrial activities related thereto;

- $\quad$ horizontally spread of the crisis effects, in complementary activities.

Between the industrial activities, the most affected by the crisis were:

- the metallurgy - recording the greatest reduction of activity in this period, the production being with 49.9 \% lower than in the first 5 months of 2008;

- $\quad$ the industry of building materials - their production being with $31.4 \%$ less than during the first 5 months of 2008 ;

- $\quad$ motor industry road transport, whose production has been with $12.7 \%$ lower than in the first 5 months of 2008 ;

- $\quad$ rubber products industry and plastics - production with $16.6 \%$ less than in the same period.

3. Activities which have not been affected by the crisis:

- industries on which there has been no noticeable negative effects of economic and financial crisis, for example, in electrical equipment industry production reduction has been insignificant (-0.2 \%) for the first 5 months;

- activities where there have been increases of production in the last quarter of 2008. For example, in the food industry, in the fourth quarter of 2008 production 
increased by more than $9 \%$ as compared to the same period in 2007. During the first 5 months of the year 2009 food production has reduced by $4.2 \%$ as compared to the same period of 2008. This development follows a trend of precluding all types of consumption values of the population, in conditions of crisis; first those covering needs higher order after that, gradually, the other types of inputs; satisfying basic needs, the food products and those associated with them were the last affected by less income, the loss of the job, uncertainty as to future revenues, etc. In the medium term, however, the domestic demand of food products remains relatively constant.

In conclusion, the effects of the different economic crisis on industrial activities, the size of the economic entities, their flexibility, the ability to adapt and respond to the risks inherent in crisis and transition through to the new market conditions have created the conditions for structural changes in the industrial sector.

\section{The evolution of the industrial sector in Romania in post-crisis}

After analyzing the evolution of industry in the European Union in the last 10 years, from the point of view of the weighting of gross value added obtained in industry including energy industry, in total economy [http://epp.eurostat.ec.europa.eu/] (tab.1), we notice that this has decreased from $21.8 \%$ in 2001 to $20.2 \%$ in 2007 (with the downward trend of relative stability around this weights since 2005) as well as it had in the economic crisis years to fall to $18.1 \%$; recovery started in 2010. Same trend is specific too the other countries of the EU, the difference between them due to the least, three fundamental coordinates: participation of the industries sector to create GDP, the size of the decline of this sector, the potential for recovery in post-crisis.

In the case of Romania's situation, the relatively large weighting of industrial sector to GDP creating illustrates, as yet, insufficient exploitation of the potential services sector including the services of scientific research and technological development, which are intended to provide technical support, human and materiel necessary modernization industry. However, recover the affected industry crisis has been, in Romania, higher than the European average and many developed countries on the continent. In this sense, gross value added obtained within Romanian industry in the year 2010 has increased by 7.4 percent as compared to 2009, while the growth in the EU is of only $3.31 \%$.

Table 1 Gross value added - Industry, including Energy (\% of all branches).

\begin{tabular}{|c|c|c|c|c|c|c|c|c|c|c|}
\hline Geo\Time & $\mathbf{2 0 0 1}$ & $\mathbf{2 0 0 2}$ & $\mathbf{2 0 0 3}$ & $\mathbf{2 0 0 4}$ & $\mathbf{2 0 0 5}$ & $\mathbf{2 0 0 6}$ & $\mathbf{2 0 0 7}$ & $\mathbf{2 0 0 8}$ & $\mathbf{2 0 0 9}$ & $\mathbf{2 0 1 0}$ \\
\hline EU (27) & 21.8 & 21.1 & 20.5 & 20.4 & 20.2 & 20.3 & 20.2 & 19.8 & 18.1 & 18.7 \\
\hline Bulgaria & 22.2 & 22.5 & 23.3 & 22.7 & 23.2 & 23.9 & 24.5 & 22 & 22.1 & 23.1 \\
\hline Germany & 25 & 24.7 & 24.7 & 25.3 & 25.4 & 26.1 & 26.5 & 25.7 & 22.4 & 23.8 \\
\hline France & 17.2 & 16.6 & 16 & 15.5 & 15.1 & 14.5 & 14.3 & 13.7 & 12.5 & $:$ \\
\hline Hungary & 25.9 & 24.7 & 24.9 & 25.7 & 25.2 & 25.5 & 25.5 & 25.1 & 25.5 & 27.2 \\
\hline Poland & 22.5 & 22.3 & 23.7 & 25.2 & 24.7 & 24.7 & 24.5 & 24.3 & 24.3 & 24.5 \\
\hline Romania & 29.4 & 30 & 27.8 & 27.9 & 28.1 & 27.8 & 27.5 & 25.8 & 27 & 29 \\
\hline Sweden & 23.6 & 23.3 & 23 & 23.2 & 23.3 & 23.2 & 22.9 & 21.6 & 19.3 & 20.9 \\
\hline U.K. & 20.5 & 19.1 & 17.8 & 17.1 & 16.9 & 16.9 & 16.3 & 16 & 14.7 & 15.3 \\
\hline
\end{tabular}


Regarding the distribution of the turnover on industrial groups, in 2011, in Romania, this highlights significant weights intermediate goods industry (27.59\%), energy industry $(27.57 \%)$ and the capital goods industry (21\%). The counties involved, for the most part, the turnover of 100037 mil.lei, of intermediate goods industry, are: Bucharest (9743 mil.lei), Olt (6375 mil.lei), Galați, Timiș and the slightest: Vaslui (71 mil.lei) (Fig.1).

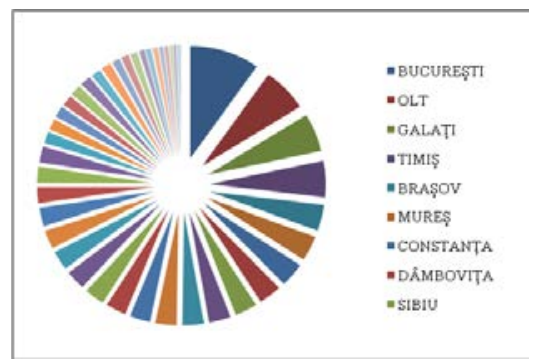

Figure 1 Distribution of the turnover of intermediate goods industry in counties, in 2011

Source: Processed http://www.minind.ro/reindustrializare/documente.html, 4.04.2013

The energy industry, with a turnover of 99965 mil.lei, is characterized by a distribution of turnover concentrated in only a few counties: Bucharest, Prahova, Constanța, the vast majority of counties having a very low participation to the energy supply of the country (Fig.2).

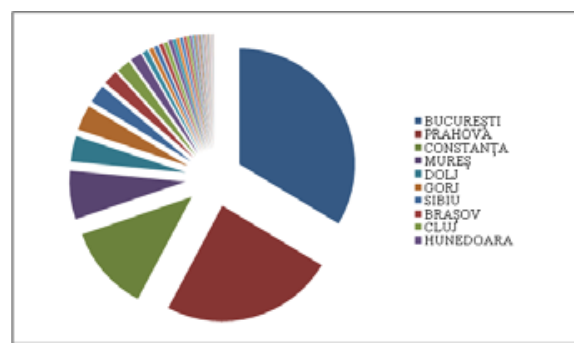

Figure 2 Distribution of the turnover of energy industry, in counties, in 2011 Source: Processed http://www.minind.ro/reindustrializare/documente.html, 4.04.2013

The capital goods industry, with a turnover of 76124 mil. lei, obtained in 2011, the highest turnover in the counties: Argeș (17398 mil.lei) and, from a great distance, Timiş (6641 mil.lei), Cluj, Braşov, Arad, Bucharest. The lowest participation to the creation of the turnover in this industry held counties: Suceava, Harghita, Giurgiu, Botoșani, Covasna, Vrancea, Ialomița, each, with turnover less than 200 mil.lei (Fig.3).

In the industry of goods in current use (Fig.4), the counties who have obtained the highest turnover are: Bucharest (9321 mil.lei), Ilfov (5345 mil.lei), Prahova, Timiș and at the opposite pole is located counties: Giurgiu (151 mil.lei) and Mehedinți (100 mil.lei).

Analyzing the situation of industrial development in the counties of Romania (Fig.5), the distribution of major industrial groups shows that in some counties predominate a group of industries - capital goods industry being prevalent in the counties Argeș, 
Arad, Cluj, Brașov, Timiș, while intermediate goods industry holds the biggest turnover of the total industries in counties of Olt, Neamț, Galați, Suceava, Dâmbovița, Bistrița-Năsăud, Alba, Caraș-Severin, Vâlcea, etc. It is the group of industries with the highest representation in terms of the distribution of turnover in the counties. Industry of goods in current use predominates the counties industry of Harghita, Ialomița, Ilfov, Vaslui and Vrancea, but absolute turnover (total industrial sector, but also for this type of industry) illustrates a relatively weak development of this group of industries. Energy industry occupies the most important place in the development of industrial counties of Prahova, Gorj, Constanța, Bucharest, Mureș. The durable goods industries and the waste collection services does not occupy dominant positions in the industrial sector of any county.

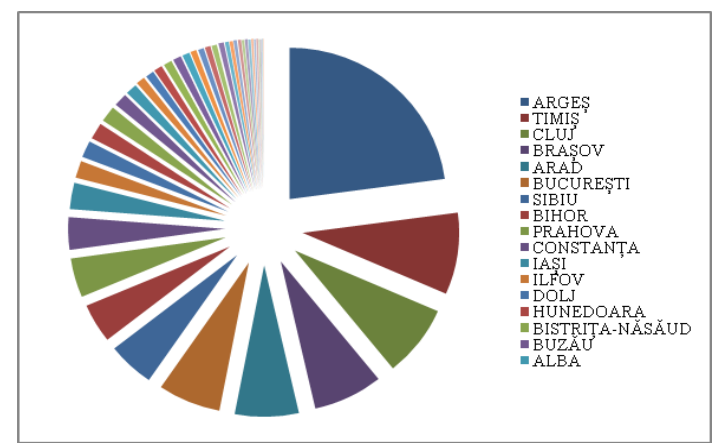

Figure 3 Distribution of the turnover of the capital goods industry, in counties, in 2011

Source: Processed http://www.minind.ro/reindustrializare/documente.html, 4.04.2013

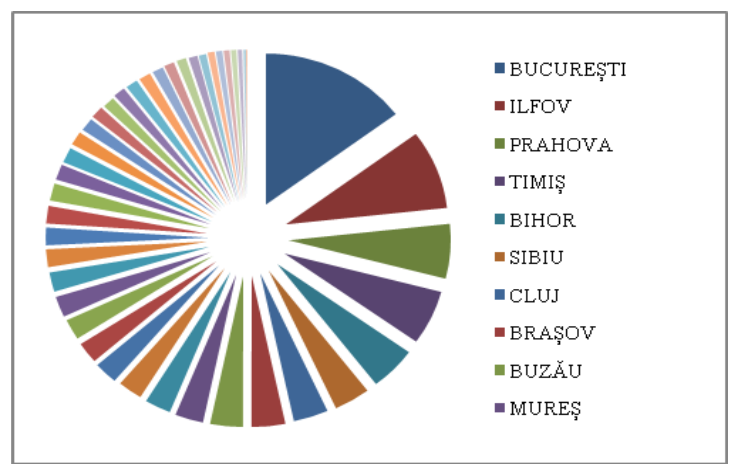

Figure 4 Distribution of the turnover of the industry of goods in current use, in counties, in 2011

Source: Processed http://www.minind.ro/reindustrializare/documente.html, 4.04.2013 


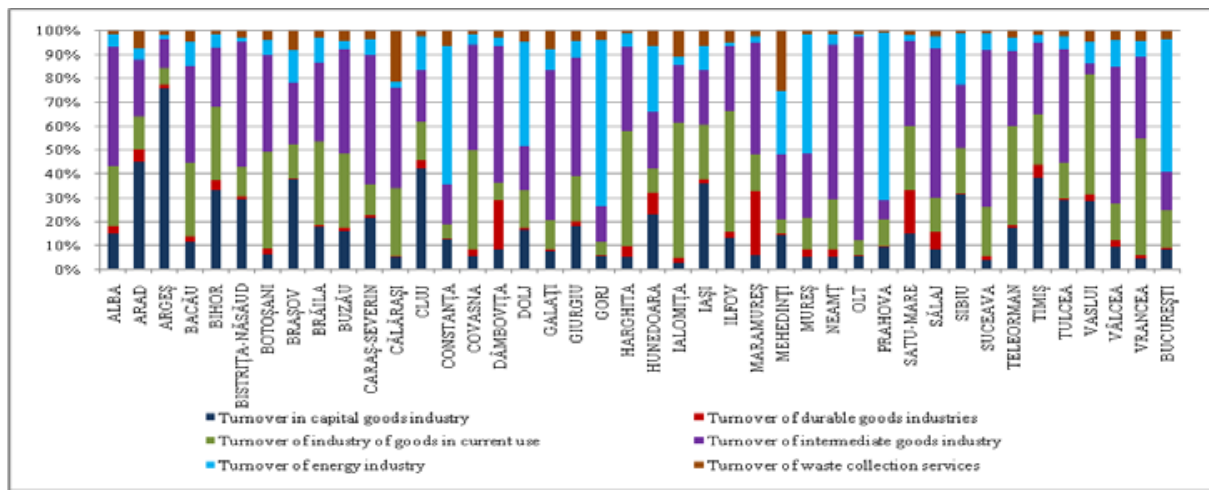

Figure 5 Distribution of turnover in the industry, industrial groups, in 2011

Source: Processed http://www.minind.ro/reindustrializare/documente.html, 4.04.2013

Analyzing the situation of Romania's industrial sector in 2011 (Fig. 6) noted that the counties of Arad and Argeș are the only counties where the number of employees in the capital goods industry predominates, as compared to the number of employees in other industries. In intermediate goods industries, well represented at the national level in most counties, the share of employees in comparison to other industries is relatively higher, without exceeding $50 \%$ of the total, in Neamt and Suceava counties. Counties where the number of employees in the industry of goods in current use, compared to other industries, are: Botoșani (58.48\%), Vrancea, Călărași, Vaslui, Ialomița, Bihor and Brăila, in these counties working more than $50 \%$ of the total employees in the respective counties. As regards the labour force involved in the energy sector, that predominate in the structure of industrial employment only in the case of Gorj county (58.53\%).

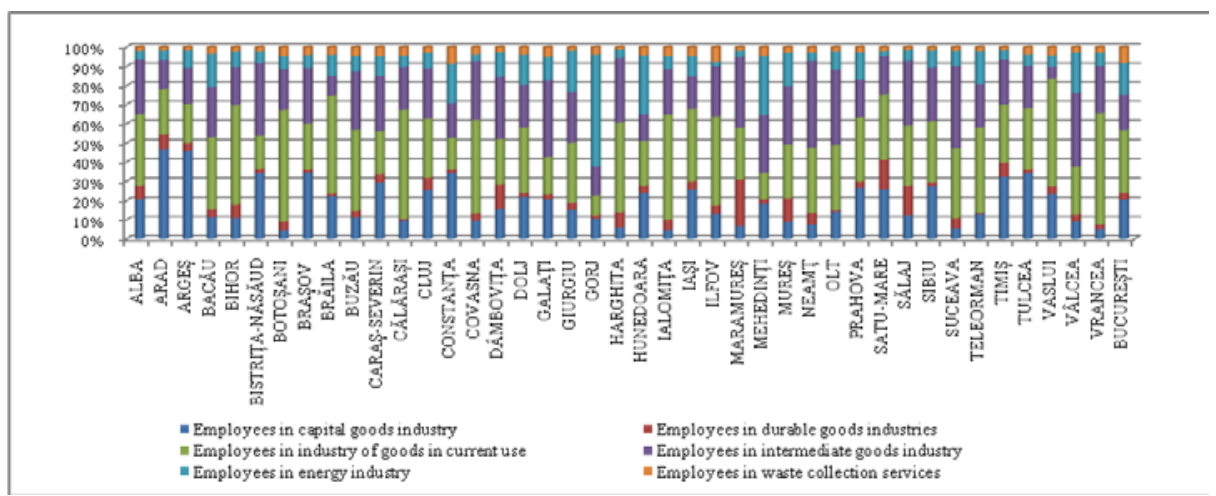

Figure 6 Distribution of employees in the industry, industrial groups, in 2011 Source: Processed http://www.minind.ro/reindustrializare/documente.html, 4.04.2013

In view of the turnover/employee in the Romanian industry, in 2011 (Fig.7) the national average was 263.03 th.lei/employee; over the average value were 10 counties of which Prahova, Constanţa and Bucharest were detached compared to others. At the negative extreme, with very low turnover/employee, much lower than the national average, have placed the counties of Teleorman, Covasna, Vrancea, (102.49 th.lei/employee) and Vaslui (93.03 lei/employee). 


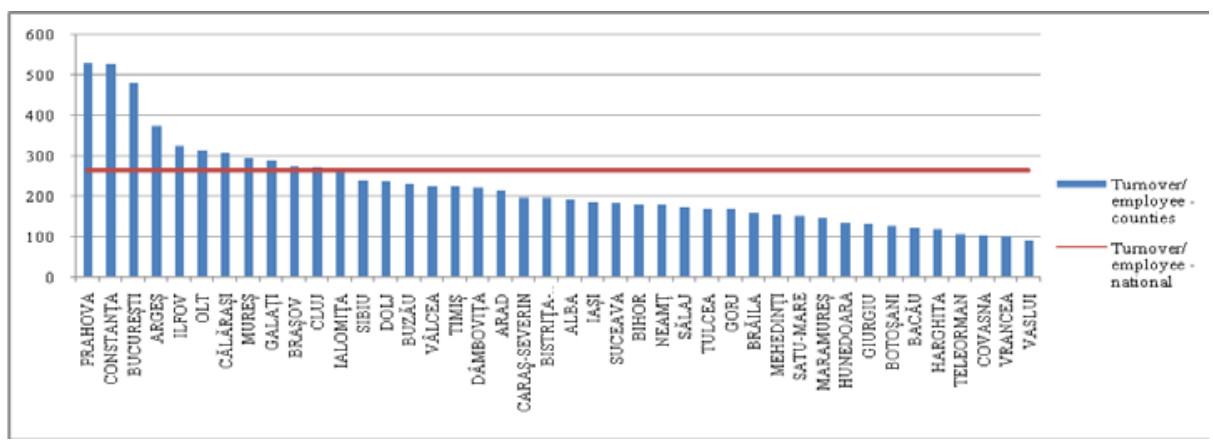

Figure 7 Turnover/employee industry in Romania, in 2011

Source: Processed http://www.minind.ro/reindustrializare/documente.html, 4.04.2013

In the capital goods industry, the situation is as relatively similar with the total industry average, in the sense that more than the national average is located a small number of counties (9) of which Argeș (610.88 lei/employee), Bihor, Constanța lead detached, and the other 33 counties are below the national average; counties of Satu Mare, Gorj, Covasna (59.14 lei/employee) have the poorest results in terms of turnover/employee (less than lei/employee). These latter situations reflect both a human resources policy ineffective, a technical and technological infrastructure deficit as well as a faulty management of the business in the counties concerned.

\section{Recent evolution of the Romanian industry - prerequisite of the future developments in the European context}

In september 2013 compared with august 2013, the industrial production increased by $19.5 \%$ [http://www.insse.ro/cms/]; at the level of the industrial groups, there have been production increases in: capital goods industry with $39.9 \%$, the durable goods industry with $19.7 \%$, intermediate goods industry with $13.0 \%$, the industry of goods in current use with 9.3\%. Only one industry which has registered decrease of production, in this range, it is energy industry $(-1,9 \%)$. From the point of view of turnover, the total industry, this has increased by $11.4 \%$, increase due to the capital goods industry, with $32.7 \%$, durable goods industry, with $12 \%$, intermediate goods industry, with $8.2 \%$, energy industry, by $7.6 \%$. The industry of goods in current use has recorded a decrease of $2.5 \%$. This reflects a good evolution of the entire industrial sector but, more particularly, the capital goods industry which support and develop the base necessary to ensure the capital goods within the country but also potential for export. Between industries in this group, significant increases in production have been manufacture transport motor vehicles, trailers and semi-trailers (61.4\%), manufacture computers and electronic products and optical (58.4\%), electrical equipment manufacture (33.8\%), manufacture of machines, machinery and equipment n.c.a. (26.0\%).

After analyzing the evolution of industry at an interval of one year, September 2013 September 2012 [http://www.insse.ro/cms/], note that the industrial production registered a growth of $10.0 \%$; The industrial groups have registered increases in durable goods industry, with $13.8 \%$, in intermediate goods industry, with $13.0 \%$, in capital goods industries, with $11.4 \%$ in industry of current use goods, with $7.9 \%$, and in energy industry, by $1.6 \%$. Turnover in industry achieved in September 2013, was 
higher by $6.1 \%$ compared to September 2012; This increase was mainly due to the increase in the intake of capital goods industries with $10.7 \%$, of the energy industry with $7.5 \%$, durable goods industry with $4.3 \%$, the industry of current use goods industry with $4,1 \%$, in intermediate goods industry by $3.7 \%$. Particularly dynamic were, in the meantime, manufacture of electrical equipment (27.3\%), manufacture of other transport equipment (23.5\%), manufacture of machinery and equipment n.e.c. (by 21.6\%), manufacture of motor vehicles, road transport of trailers and semi-trailers $(13.8 \%)$. It is significant that, in the last year, the whole industrial sector labor productivity increased by $9,8 \%$.

Raising industrial production and total components has been driven by external demand, raising the total to some industries, of which the capital goods industry.

One of industrial groups in an uptrend in Romania is capital goods industry [www.minind.ro]. Of these, making autos, machinery and equipment, in our country, according to European Commission estimates, the greatest growth potential in untapped export, respectively $18.6 \%$. In the EU, this industry generates the highest value added of the manufacturing industries $(10.9 \%$ of value added of the manufacturing industries, $2.9 \%$ of the value added of the non-financial sector). Machinery industry, machinery and equipment represents an important sector of the Romanian industry, helping to develop, modernize and proper functioning of other industrial sectors, with a share in GDP of 2.5\%. Machinery industry, machinery and equipment include complex technological lines with long manufacturing cycle, intended for the execution of capital goods, equipment for small and large series, intended for transport, agriculture, consumer goods and components of large mass production or series.

Industrial production of this industry grew 38.59\% in 2011 compared with 2009; exports increased by $56.46 \%$ and the average number of employees increased by $2 \%$ in the same period. Machinery and equipment industry is based on the research, development and innovation. Still before the economic and financial crisis, the sector of machinery and equipment began to grow as a result of the investment of 'greenfield', leading to both increased productivity and the number of firms in this sector. Enjoy a balanced territorial distribution in terms of production companies. The main target of companies in this sector is working with other companies in the EU in order to facilitate access to modern technologies and licenses and easier to penetrate the European and international market. Among the proposals that the decision-makers they have done to support the development of the industry, including: the establishment of a body for market surveillance, the adoption of measures to reduce taxation, increasing the stability of the law relating to investment arrangements, funding programs, etc. set up a territorial network to harness the knowledge and image cross-institutional relations, the establishment and support of industrial parks and business incubators, improve conditions for investment, credit, encouraging and supporting activities related to the capitalization of the companies, reviewing tax policy for the benefit of economic operators whose production is more than $50 \%$ for export, the simplification of tax from tax documentation and taxation, investing significant amounts in the fields that encourages industrial innovation, taking active measures to increase the number of specialists and executive staff, etc.

Positive development and the trend of increasing industrial production, turnover and labour productivity in industry falls within the coordinates of Romania's economic development, in the context of the European Union's economy [http://europa.eu/].

The Europe 2020 strategy, the industry is an essential component of the new model of development. Industrial policy will strengthen the competitiveness of the Union concerned, will create conditions for positive real economic growth, create jobs and 
will allow the transition to a low carbon economy and effective use of resources. To do this, it is necessary to include policies with an impact on costs, prices and innovation-based competitiveness of the industry and individual sectors, in line with the single market policies, comercial policies, transport, energy, social and environmental policies, consumer protection policies. Differentiated approach should be continued for each sector, taking account of the whole value chain and supply chain, including outside the EU, access to energy and raw materials to after-sales service and recycling of materials, as well as periodic reporting by the European Commission with regard to competitiveness, industrial policy, the performance of the EU.

Raising productivity, efficiency of use of energy and material resources, tangible assets and performance of intangible assets-are also possible by ensuring innovation. Promoting the introduction and marketing of generic essential technologies are considered necessary for widening the range of products and the development of new industries.

Support an industry performance is given, inter alia, the upgrading of the skills of the workforce. This requires the formation of networks between specialists, to exchange information and good practice between EU countries, important objective and industrial modernisation.

Industry in Romania, as well as the EU industry from other countries must speed up the transition towards a low-carbon economy, efficient in the use of energy and resources.

Implantation of human dimension and territorial are key elements in the relaunch of the Romanian industry. Increasing the role of industry in the economy of Romania is motivated and leverage effect on the whole economy, particularly with regard to employment.

Given the time horizon 2030, the policies in the field of industrial development in Romania will follow the strategic directions and objectives of the Romanian economy and the fundamentals of developments within the EU, in accordance with the sustainable development coordinates. [www.insse.ro/cms/]. Influence factors of the evolution of the different industrial sectors over the medium term are:

- maintaining and developing a business environment attractive to investment growth, technological modernization and renewal of processes and products;

- consideration of the environmental impact of products throughout their life cycle (design, manufacture, assembly, marketing, distribution, sale and use to recycling and disposal);

- compatibility research, development and innovation with the real needs of industry and the market requirements in order to obtain competitive advantages and to reduce the technological gap and productivity compared to the more advanced countries in the EU;

- promotion of digital technologies in the management of companies, from design to production and marketing, etc.;

- development and promoting hygiene in the competitive environment in business development in the context of the European competitive environment;

- $\quad$ improving sectoral assistance and modernization of the role of public authorities in the development and application of industrial policy;

- $\quad$ supporting direct investment as a source of capital, know-how, technology and management. Investment plays a double role in the economy - is an important and instable component of costs, their changes can have a big influence on aggregate demand that will affect output and employment, but also positive 
determination of capital accumulation, thus helping to increase the production potential of the country and supporting long-term economic growth (Samuelson);

- promoting the development of small and medium enterprises (SMEs) in the sectors of the processing industry for the production of high-quality products with low cost, adjusted for market requirements;

- increasing material resources and energy consumed with an average annual rate of $3-4 \%$, by:

- macroeconomic structural changes - increased proportion of services at $48.8 \%$ in 2005 to $60 \%$ by 2020 and $70 \%$ in 2030 ;

- structural changes in cross-cutting energy and material sectors share intensive industry;

- minimum reduction of 1.2-1.5\% per year specific consumptions of energy and materials and losses in the manufacturing industry, in sectors of energy and transport, and residential construction as a result of increased investments for technological modernisation of infrastructures, energy management and technological quality;

- $\quad$ increase 2-3\% per year of the share of high value-added products, based on the average and high technologies and services in the export structure;

- improve technical and economic performance and quality of products and services;

- optimizing the commercial management, both on the management of the suppliers of raw materials, materials, etc. (especially energy) and on the management of clients.

Achieving these objectives will ensure that over $60 \%$ of economic growth can be achieved without any additional consumption of energy and material resources. Also on this basis it will be possible to reduce the pace of depletion of reserves at the main types of raw materials, lower costs, increase competitiveness and thereby ensuring the sustainability of economic growth.

\section{Conclusions}

Industry development is the foundation for the modern development of the national economy - a modern agriculture, efficient and high quality services, and, furthermore, support for the development of other industrial activities.

Affected by the transition from the command economy to market economy system, Romanian industry has been, for a long time, under the specter of massive negative industrial structures and buildings, technical and moral wear of the technologies used, productivity of the production factors, poor investment in scrapper innovation and technology policy, and institutional factors with difficulties of the adaptation to the new requirements of the market for industrial goods, etc.

Once completed this difficult transition, in which the reform towards another type of industry - expected was left, Romania had to deal with the transition through the economic and financial crisis, which has affected the sensitive start-up again. However, the decision-makers in the industrial sector have understood that the business environment can restart, as a whole, just by pushing forward, strengthening and modernization of the industry. The desire to initiate or develop business in the field of industry has been transposed in the Romanian joined the industrial policy EU policy which, apart from economic and social objectives targeted, focused and longterm relationship with the natural environment. In this sense, Romanian industry targeting, at present, by policies developed and implemented - of diversification in production, technical and technological innovation, increase quality, increase of 
production obtained, increase in turnover, the export of the products obtained, the productivity of production factors, etc. are not only re-industrialization but sustainable industrialization.

\section{References}

Danu, M.C. (2013), Mediul de afaceri european, Editura Alma Mater, Bacău.

Gross value added - Industry, including Energy, available on http://epp.eurostat.ec. europa.eu/.

Indicatorii dezvoltării durabile în România, available on http://www.insse.ro/cms/.

Indicii producției industrial, available on http://www.insse.ro/cms/.

Industria românească în perioada de criză, Comisia Națională de Prognoză, available on http://www.cnp.ro/ro/studii.

Reindustrializarea României, available on http://www.minind.ro/reindustrializare/ documente.html.

Samuelson, P. (2000), Economie politică, Editura Teora, București.

Strategia de dezvoltare durabilă a României, available on http://europa.eu/. 